\title{
The Effect of Developing E-Marketing and Efficiency Capabilities on the Improvement of B2B Marketing Performance
}

\section{El efecto de desarrollar capacidades de E-Marketing y eficiencia en la mejora del rendimiento de marketing $B 2 B$}

\author{
JAFARI, Sajad $\dagger \&$ SHIRAZIAN, Zahra*
}

Department of Management, Malayer Branch, Islamic Azad University, Malayer, Iran

ID $1^{\text {st }}$ Author: Sajad, Jafari / ORC ID: 0000-0002-0129-005X, Researcher ID Thomson: F-7621-2019

ID $1^{\text {st }}$ Coauthor Zahra, Shirazian / ORC ID: 0000-0003-2457-9216, Researcher ID Thomson: I-1315-2018

DOI: $10.35429 /$ EJM.2019.22.10.27.38

Received: February 28, 2019; Accepted: April 25, 2019

\begin{abstract}
This study aimed to investigate the effect of developing emarketing capabilities and efficiency on the improvement of B2B marketing performance. The present research was an applied and descriptive survey. The statistical population of the study encompassed the employees operating in Malayer Furniture Brand $(\mathrm{N}=156)$ and the sample size was 113. The data collection tool was a questionnaire. To assess the validity, the content validity and confirmatory factor analysis were adopted and the results indicated the appropriateness of the factor analysis in identifying the structure of the model. Cronbach's alpha was used to measure reliability and the results suggested that the value of each research questionnaire component was greater than 0.7 . The data were analyzed using structural equation modeling by Smart PLS software. The results showed that the development of e-marketing capabilities had a positive and significant effect on improving the B2B performance of the Malayer Furniture Brand. The development of efficiency capabilities also positively and significantly improved the B2B performance of the Malayer Furniture Brand.
\end{abstract}

Development of e-marketing capabilities, B2B performance improvement, Efficiency capabilities

\begin{abstract}
Resumen
Este estudio tuvo como objetivo investigar el efecto del desarrollo de las capacidades y la eficiencia del marketing electrónico en la mejora del rendimiento del marketing B2B. La presente investigación fue una encuesta aplicada y descriptiva. La población estadística del estudio abarcó a los empleados que operan en la marca de muebles Malayer $(\mathrm{N}=156)$ y el tamaño de la muestra fue de 113 . La herramienta de recolección de datos fue un cuestionario. Para evaluar la validez, se adoptaron la validez del contenido y el análisis factorial confirmatorio y los resultados indicaron la idoneidad del análisis factorial para identificar la estructura del modelo. Se usó el alfa de Cronbach para medir la confiabilidad y los resultados sugirieron que el valor de cada componente del cuestionario de investigación fue mayor que 0.7. Los datos se analizaron utilizando un modelo de ecuación estructural mediante el software Smart PLS. Los resultados mostraron que el desarrollo de las capacidades de marketing electrónico tuvo un efecto positivo y significativo en la mejora del rendimiento B2B de la marca de muebles Malayer. El desarrollo de capacidades de eficiencia también mejoró de manera positiva y significativa el rendimiento B2B de la marca Malayer Furniture.
\end{abstract}

Desarrollo de capacidades de marketing electrónico, Mejora del rendimiento B2B, Capacidades de eficiencia

Citation: JAFARI, Sajad \& SHIRAZIAN, Zahra. The Effect of Developing E-Marketing and Efficiency Capabilities on the Improvement of B2B Marketing Performance. ECORFAN Journal-Mexico. 2019, 10-22: 27-38.

\footnotetext{
* Correspondence to Author (zahra.shirazian@gmail.com)

$\dagger$ Researcher contributing first Author.
} 


\section{Introduction}

The e-marketing capabilities are a process beyond the traditional marketing, which is performed through Internet technology. This method establishes a mutual relationship between the company and its customers. Ecommerce pursues the same goals as the traditional marketing's, and the only difference is that the e-commerce uses new technology and techniques to innovate and improve performance. E-marketing is considered as a reciprocal relationship and, in addition to providing the possibility of expanding massive information, it has also provided the grounds to obtain information from the market and other competitors (Vorhies et al., 2009). Efficiency refers to spending minimum energy for maximum work. The managers are directly in charge of improving the efficiency that would result in increasing productivity and, consequently, reaching the objectives of the company in terms of marketing.

The term efficiency is limited and is used to refer to the intra-organizational operations. Business to Business (B2B) means trading performed between a business and a business or a merchant and a merchant. This type of marketing refers to business activities between merchants and wholesalers or major retailers and retailers. The B2B system is the first method of doing electronic transactions and still provides the maximum profit. In B2B business, the merchants also have to identify the intermediaries in addition to their customers. One of the first major companies was CISCO Inc., which developed their e-commerce website in July (1996), and then major computer companies such as Microsoft and IBM offered their commercial software that provided the possibility of shopping via the Internet (Pierre, 2001).

\section{Significance and Necessity of the Study}

Marketing capabilities are integrated and coherent processes designed to apply collective skills, knowledge and resources of the company, detect market needs, and improve the value of the company's products and services, through which and the company can adapt itself to the variable conditions of the market and use market opportunities to deal with competitive threats.
Marketing capabilities represent the specific capabilities of a company in identifying target markets, strategies, and mixes of developing markets, causing the maintenance of relationships with loyal customers. Previous studies show a positive relationship between marketing capabilities and company performance $(\mathrm{Wu}, 2013)$. Competition has gotten more intense in e-marketing and longterm relations need to be emphasized. The ecommerce wave has affected almost all companies and, in particular, companies operating in the furniture industry as such they are obliged to enter the e-commerce industry.

The strategic goals of e-commerce, as a traffic light, facilitate all efforts and measures to deploy e-commerce and gain competitive advantage in the electronic world (Samiee, 2008). It seems to be a general agreement that the companies, if they want to succeed in their business and marketing environments, should also improve their marketing performance and efficiency. Appropriate employment of human resources to improve the marketing efficiency as the most valuable and foremost wealth in each company has become an issue of great importance (Anastasia et al., 2015).

Hence the efficiency of human resource marketing is one of the key pillars in any institution or company. The buyer's decisionmaking process is no longer a linear process so that the buyer does not first search to select a company and ultimately make a purchase from the selected company.

On the other hand, it is a fluid process and a cycle through which the buyer constantly surfs various channels (websites, social networks, specialized blogs, etc.) to obtain information about his concerned commodity, investigates different companies and brands and constantly evaluates the findings obtained about his concerned brands (Turban et al., 2006).

\section{Theoretical Background of the Study}

\section{Marketing capabilities}

In recent studies, marketing capability is defined as the process of applying the organizational knowledge, skills, and resources to create added value for goods and services, meet competitive needs, and respond to market-related needs. 
The importance of learning processes in the development of marketing capabilities has been emphasized, especially when employees can quickly solve their marketing problems using their knowledge and skills. In order to illustrate the marketing capabilities of the company, some specific marketing processes which can be consistent with the company's competitive strategy, are outlined.

\section{Efficiency}

The term efficiency is more limited and is used to refer to the operations performed within an organization. An organization's efficiency refers to the amount of resources consumed to produce a product and is measured based on the consumption to product ratio (Mohan \& Ray, 2004). If an organization can afford to spend less resources in comparison to other organizations to reach its specified goal, its efficiency is greater. In other words, efficiency refers to the minimum time or energy spent on the maximum work. Or, it is in fact the proportion of the performed work to the work to be done (Mohan \& Ray, 2004). Various factors, including training, job turnover, job enrichment, and employees' empowerment, enhance the efficiency in an organization (Weill, 2004).

\section{B2B Marketing}

Business to Business marketing, commonly known as B2B marketing, includes selling products or services to another company. The B2B marketing techniques rely on the basic principles of consumer marketing; however, they are conducted uniquely (Zhang et al., 2012). For the B2B buyers, only the price and potential profit of the product is of importance. In $\mathrm{B} 2 \mathrm{~B}$ marketing, the businessmen have to recognize customers and intermediaries. Looking for new ways to promote relationships through social media is currently a hot bed of debates throughout the world and in B2B marketing (Sadi \& Noordin, 2011).

Social networks have created a new channel for conversations and communications among different businesses. Professional and opportunistic B2B companies have found innovative techniques to exploit social media. In this model, retailing does not matter, and buyers are looking for wholesales with high profit rates since retailing is not risk free and buyers are not eager to buy products from the Internet (Sadi \& Noordin, 2011).

ISSN-Print: 2007-1582- ISSN-On line: 2007-3682 ECORFAN $^{\circledR}$ All rights reserved.
Cisco Co. was a leading company in initiating e-commerce website in 1996. Within a short period, major companies such as Microsoft and IBM then came into the market and marketed their commercial software. Today, B2B e-commerce has achieved the highest progress in e-commerce, and it is expected that this type of business grows faster in the near future (Zhang et al., 2012). In order to advance in this business, the observance of following points is of essence: hosting information webinars, setting up the industry booth at popular and well-known business fairs, sending an email newsletter as an industry expert, and informing about the status of the company, having an active and interactive participation in social media, attending the industry network events, and establishing favored relations with buyers (Maswera et al., 2008).

\section{Empirical Background of the Study}

- Amiri et al. (2016) investigated the factors affecting the adoption of e-commerce in Iran's agricultural sector. The results of their study indicated that attitudes played a mediating role in the relationship between perceived usefulness and security, operational, financial, and time risks with the acceptance of ecommerce.

- Saeidi Garghani and Naser Asadi (2016) examined the impact of marketing on the effectiveness of implementing e-commerce strategy and found that marketing had a positive and significant effect on the effectiveness of ecommerce strategy implementation.

- Asghari and Heidari (2015) conducted a study entitled "Developing a model based on the factors affecting customer satisfaction and trust in the e-commerce sector." The results of this study provided an insight for those who work in the field of e-commerce, because they can use it to design and implement e-commerce websites with a group shopping income model.

- Samadi Pour et al. (2015) carried out a research on the impact of satisfaction and website usability on the development of efficiency and positive oral statements in electronic services. The results showed that the ability to use the website had a direct impact on customer satisfaction in e-business, and that the customer satisfaction leads to efficiency and the efficiency provokes further positive oral statements in e-business.

JAFARI, Sajad \& SHIRAZIAN, Zahra. The Effect of Developing E-Marketing and Efficiency Capabilities on the Improvement of B2B Marketing Performance. ECORFAN Journal-Mexico. 2019. 
- Zaman Pour and Sattari Ardebili (2015) researched the B2B marketing in small and medium-sized enterprises (Case study: Moghan Agro-Industry Company). The results of the study revealed a positive and significant relationship between market orientation, branding capability, and innovation capacity with B2B marketing performance.

- Rahimi (2015) conducted a research on the relationships among technological opportunities, with an emphasis on B2B marketing and performance. The results of this study showed that the technological opportunities had a positive impact on key efficiency measures such as sales, profit, and market value. The marketing mechanism through which the relationship between technology, efficiency, and performance is determined is of great importance.

- Montazeri et al. (2014) conducted a study entitled "Factors affecting the intent of shopping in e-commerce among computer website customers". The research findings indicated that the virtual companies can increase the customers' willingness for online shopping through reducing perceived risks and enhancing perceived benefits and trust by creating a safe environment and ensuring successful shopping.

- Ranjbargi and Eskandarian (2014) investigated the factors influencing the development of e-commerce application in textile and apparel companies of Isfahan province. The results suggested that the two main factors, including organizational structure (prospective and strategic management, firm size, flexibility, performance and expected efficiency) and supporting and infrastructure factors have a significant effect on the use of ecommerce tools in enterprises operating in the textile industry sector in Isfahan province.

- Monavarian et al. (2014) investigated the factors influencing the development of ecommerce (Case Study: small and medium-sized enterprises in Tehran). According to the findings, the external environment factors are divided into the macro environment factors and the industry environment factors, each of which separately affects the acceptance and development stages of e-commerce in small and medium-sized enterprises.
- Elahi et al. (2010) conducted a research study on the relationship between e-commerce and customer behavior and concluded that trust, loyalty and satisfaction interactively enhance eshopping; however, the extent and the procedure through which they affect and interact with each other in different countries varies.

- Hosseini et al. (2008) investigated the impact of e-marketing on the export performance of the distinguished exporters in the industry sector during 2000-2005 (with an emphasis on the Internet). The results revealed a positive relationship between the use of Internet in marketing activities and export performance of the concerned companies.

- Iddris and Ibrahim (2015) investigated the relationship between e-marketing and marketing performance. Their findings showed that, despite the use of electronic marketing by companies, this tool had a positive impact on their marketing performance.

- Sok et al. (2013) conducted a research on the relationship between the e-marketing capabilities, innovation, and learning with the performance of small and medium-sized enterprises. The results revealed a positive and significant relationship between the e-marketing capabilities, innovation, and learning with the performance of small and medium-sized enterprises.

- Theodosiou et al. (2012) studied the strategic orientation, marketing capabilities, and company performance, an empirical study on the concept of frontline managers in service organizations. According to this study, competition and innovation orientations lead to the development of marketing capabilities, there is a positive and significant relationship between marketing capability and performance, and marketing capability has an impact on performance.

- Mariadoss et al. (2011) conducted a study entitled "Marketing capability and innovation-based strategies for environmental sustainability (Case Study: B2B Companies). The results revealed that innovation-based strategies and marketing capabilities affect performance and competitive advantage. 
- Merrilees' et al. (2011) study entitled "Marketing capabilities: Antecedents and implications for B2B SME performance" showed that marketing and innovation capabilities were the most important factors affecting the SME performance.

- Tsiotsou and Vlachopoulou (2011) conducted a study entitled "Understanding the effects of market orientation and e-marketing on service performance." They found that market orientation had a positive and significant effect on efficiency through a dual mechanism (directly and indirectly) with regard to the mediating role of e-commerce, which improves the impact of market orientation on efficiency.

- In his research entitled "The effect of culture on creation marketing intelligence by internet and creation value in B2B organization" with regard to the increasing value of Internet in companies, Karayanni (2006) explored the techniques to achieve marketing intelligence via the Internet and investigated the relationships between intelligence obtained via the Internet and its value creation with variables such as customer relation, innovation, productivity and efficiency, and the strength of such relationships. The results showed that the Internet as a virtual business network has infiltrated the lives of organizations and has provided a large number of many opportunities for organizations. It was also determined that the value or timing of this category and the organizational culture in this category had a significant impact as well.

- Lin (2003) criticized the customer satisfaction in e-commerce. The result of his study showed that service quality in e-commerce is a way of determining the competitive advantage through customer satisfaction. In addition, customer relations in the e-commerce environment is of great importance in maintaining customer satisfaction.

\section{Conceptual Model of the Study}

In this study, Gray et al. (2017) and Supran and Sharma' (2014) e-marketing capabilities model and Gray's et al. (2017) B2B performance model were used. The researcher adapted the abovementioned models and developed the conceptual model of the present study as follows, according to which the research hypotheses were formed:

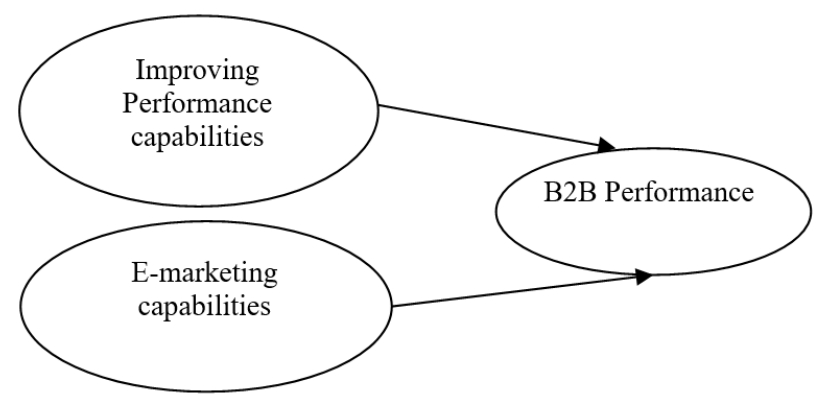

Figure 1 Conceptual Model of the Study

\section{Research Hypotheses}

1. The development of e-marketing capabilities has a positive and significant effect on improving the B2B performance of Malayer Furniture Brand.

2. The development of efficiency capabilities has a positive and significant effect on improving the B2B performance of Malayer Furniture Brand.

\section{Research Methodology}

The present research was applied in terms of the research objectives and quantitative with regard to the data type as the questionnaire and quantification of qualitative concepts and values were employed in this study. Regarding the procedure of the study, it was cross-sectional since it was performed at a point in time rather than within an interval. The statistical population of the study encompassed the staff of the Malayer Furniture Brand ( $=156)$. The study sample size was estimated to be 113 according to Morgan's Table. Simple random sampling was also used in this study.

\section{Instruments of the Study}

Questionnaires were used as the research instruments to collect data in this study. Three questionnaires were used as described below.

A. The Standardized Marketing Capability Questionnaire contains 14 questions and seven components, including: 1) providing online product catalogs; 2) upgrading products online; 3 ) online orders; 4) online payment; 5) salesperson online access; 6) Electronic shopping; and 7) participation in e-market 
B. Standardized Scale of Development of Efficiency Capability. This standardized questionnaire encompasses four components and eight items: 1) equality; 2) alignment; 3) work speed; and 4) using facilities.

C. Standardized B2B Performance Inventory: This standardized questionnaire contains four components and eight questions as follows: 1) Information multiplicity; 2) After-sales support; 3) Effectiveness of market research; and 4) Online communication.

Confirmatory factor analysis and goodness of fit indices were used to determine their validity and Cronbach's alpha was also employed to determine its reliability. The values of factor analysis and Cronbach's alpha coefficients are presented in Table 1.

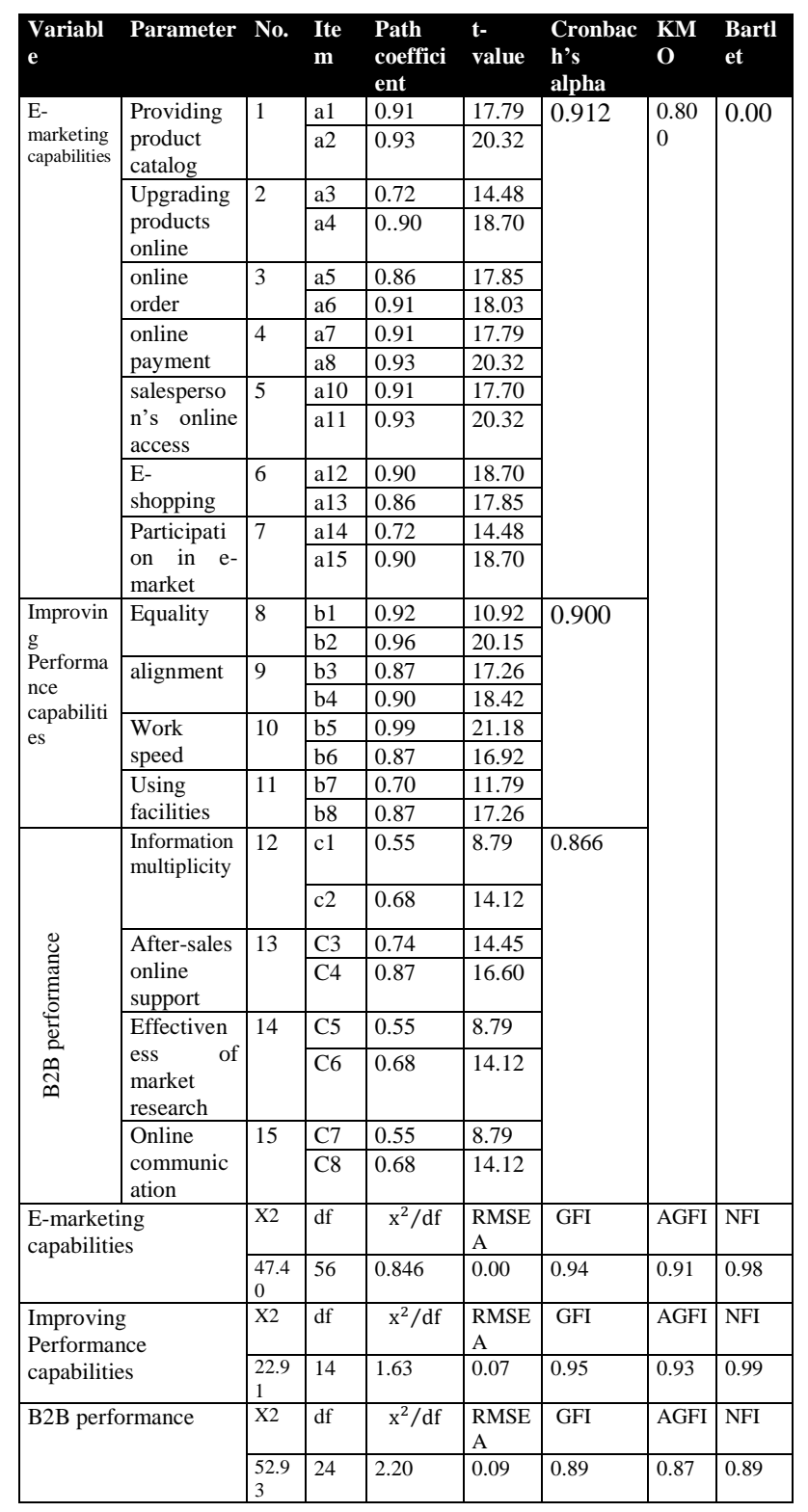

Table 1 Validity and reliability of research questionnaire
As the above Table indicates, the values of Cronbach's alpha coefficient for all components are $>0.7$; hence, the research questionnaires have an acceptable reliability. The value of KMO index for the three questionnaires was $>0.6$ and the significance level of Bartlett's statistics was $<0.05$; therefore, the research sample was sufficient to implement confirmatory factor analysis. The values of confirmatory factor analysis at the level of standard coefficients for each questionnaire were at an appropriate level, and the T-values of the factor analysis for the three questionnaires were out of +1.96 to -1.96 range and showed an appropriate level. Furthermore, the validity of the questionnaire revealed its appropriate content validity; therefore, the validity of the questionnaire can be considered as achieved. To sum up, the research tools were valid and reliable. Moreover, the goodness of fit indices in confirmatory factor analysis indicated that the questionnaires were well-fitted.

\section{Findings of the Study}

Before analyzing the data, their distribution status was evaluated using the KolmogorovSmirnov test and it was found that the distribution of the variables is not normal. Thus partial least squares method, which can be run using Smart PLS software, was used. The image output of the hypotheses estimation for path coefficients and significant coefficients is presented in the following figures.

\section{Structural Path Coefficients of Research Hypotheses}

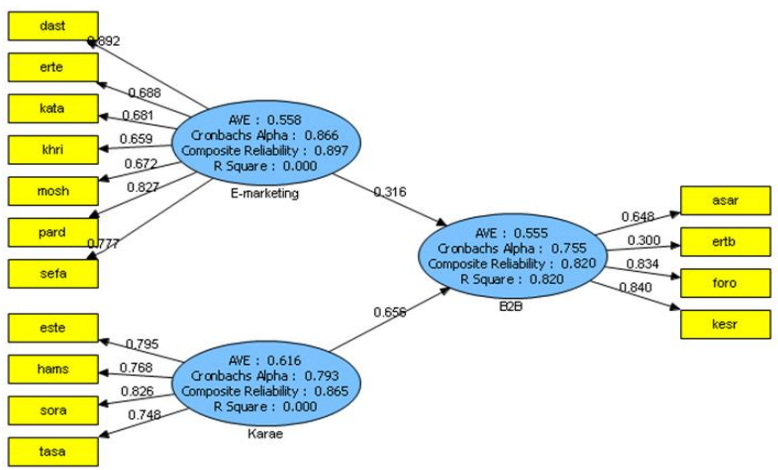

Figure 2 Estimated model of main research hypotheses in path coefficients 
The coefficients in this figure are the same standardized regression coefficients, or in other words, the same beta values in the regression model, indicating the intensity of the effect of the independent variable on the dependent variable and the mediating variable. To ensure the meaningfulness of the above coefficients, $t$ values need to be considered. Figure 3 shows these values as a graph:

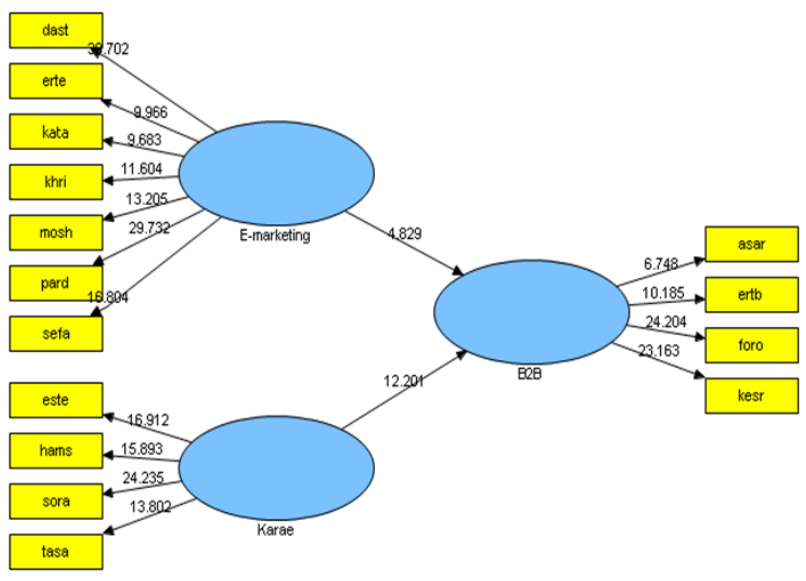

Figure 3 Meaningfulness coefficients of the estimated model for the main research hypotheses

Figure 3 presents the t-values for the estimation of the standard coefficients.

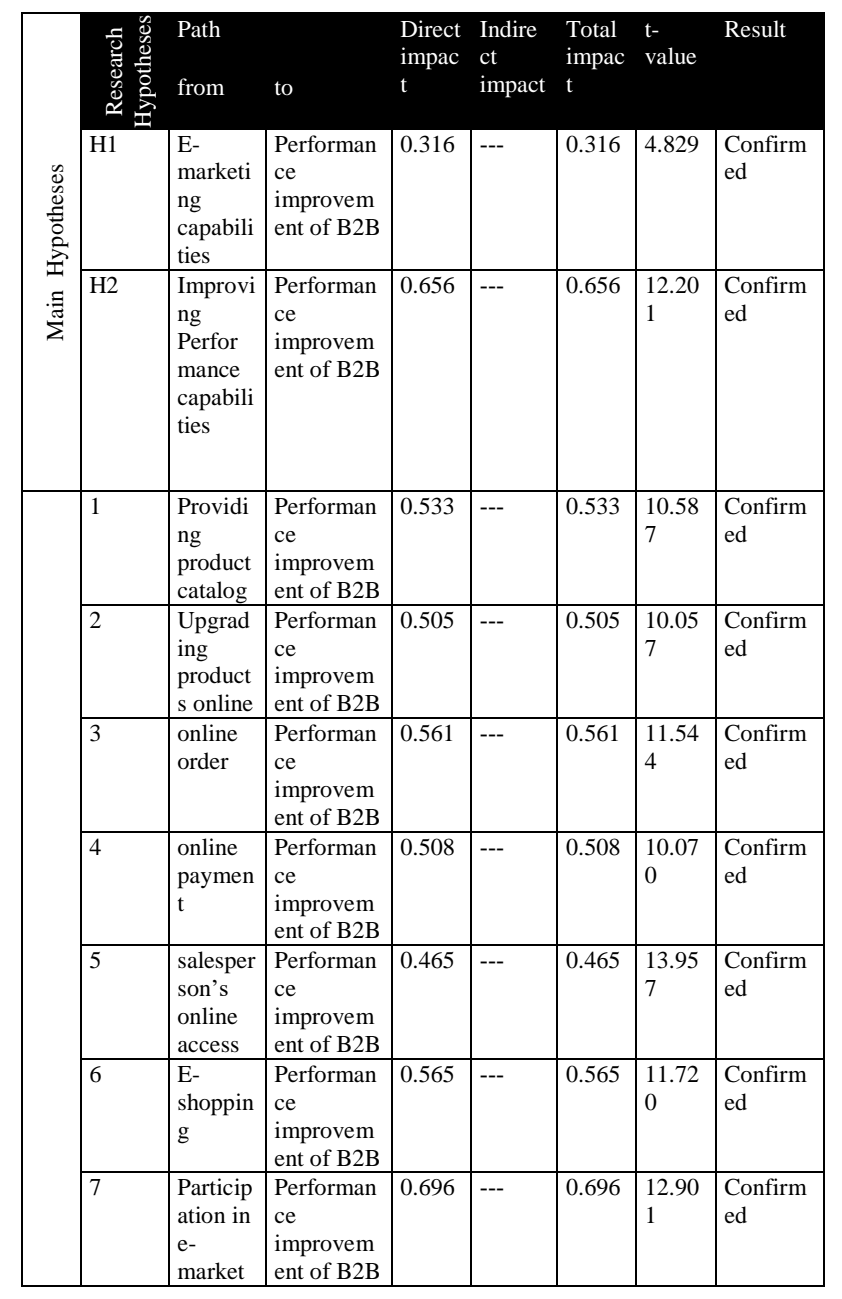

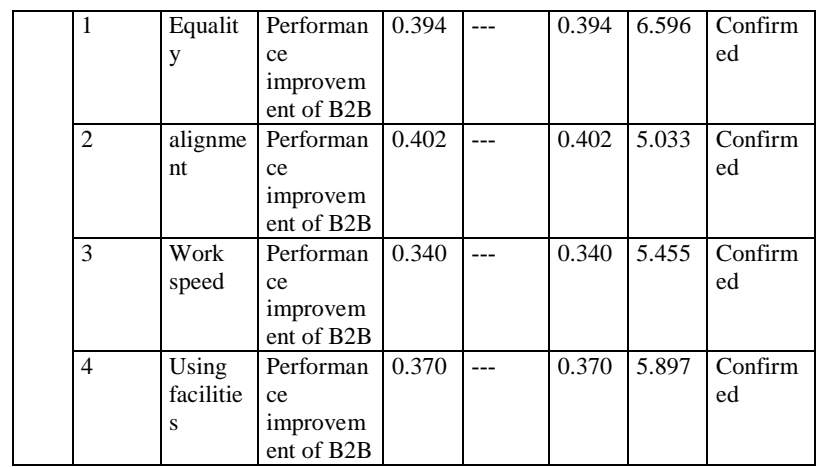

Table 2 T-values and path coefficients of research hypotheses

\begin{tabular}{|c|c|c|c|c|c|c|c|c|}
\hline \multirow[t]{2}{*}{ Variables } & \multicolumn{3}{|c|}{$\begin{array}{l}\text { External Model } \\
\text { Indices }\end{array}$} & \multicolumn{2}{|c|}{$\begin{array}{l}\text { Internal } \\
\text { Model } \\
\text { Indices }\end{array}$} & \multicolumn{3}{|c|}{$\begin{array}{l}\text { Model Quality } \\
\text { Indices }\end{array}$} \\
\hline & $\alpha$ & $\rho$ & AVE & $\mathrm{r} 2$ & Q2 & Com & Red & GOF \\
\hline E-marketing & $\begin{array}{l}0.8 \\
66\end{array}$ & 0.897 & 0.558 & |-- & 0.510 & 0.626 & --- & 0.724 \\
\hline $\begin{array}{l}\text { Performance } \\
\text { Capabilities }\end{array}$ & \begin{tabular}{|l|}
0.7 \\
93
\end{tabular} & 0.865 & 0.616 & --- & 0.518 & 0.616 & --- & \\
\hline $\begin{array}{l}\text { B2B } \\
\text { performance }\end{array}$ & \begin{tabular}{|l|}
0.7 \\
55 \\
\end{tabular} & 0.820 & 0.555 & 0.820 & 0.524 & 0.678 & 0.364 & \\
\hline
\end{tabular}

Table 3 Evaluation of internal and external indices of the model and the main research hypotheses

Since Cronbach's alpha and composite reliability values were $>0.7$, the model was assumed to be reliable. Moreover, the AVE index value was also $>0.5$; thus, the external model indices were in an acceptable condition. An evaluation of internal model indices also showed that the model was in an appropriate condition since the coefficients of determination were high and the $\mathrm{Q}^{2}$ index of Aston-Gaiser is not zero. The overall model indices were appropriate, and the GOF index confirmed that the model had a predictability of 0.724 for the research hypotheses.

\section{Discussion and Conclusion}

The analysis results of the first main hypothesis with regard to the direct effect (0.316) indicated that the effect of the development of electronic marketing capabilities on improving the B2B performance of the Malayer Furniture Brand was positive and the null hypothesis was rejected, and the $\mathrm{H} 1$ is confirmed. The $\mathrm{t}$-value for the variables 'developing electronic marketing capabilities' and 'improvement of B2B performance' was 4.829 at a confidence level of $99 \%$ and an error rate of $1 \%$, which was $>2.56$, indicating a significant relationship between these two variables in the Malayer Furniture Brand at a confidence level of $99 \%$. 
Accordingly, given that the t-value of the first main hypothesis (4.829) is greater than 2.56, the first hypothesis of the study is confirmed. In other words, the development of electronic marketing capabilities could justify $316 \%$ of the variations in improving the B2B performance of the Malayer Furniture Brand. All in all, the first main research hypothesis was confirmed. In other words, the development of electronic marketing capabilities has a significant effect on improving the B2B performance of the Malayer Furniture Brand.

This finding is consistent with the findings of some other researchers (e.g., Amiri et al., 2016; Saeidi Garghani \& Naser Asadi, 2016; Mohtaram et al., 2015; Asgari \& Heidari, 2015; Zaman Pour and Satar Ardebili, 2015; Rahimi, 2015; Montazeri et al., 2014; Ranjbargi \& Eskandarian, 2014; Monavarian et al. , 2014; Elahi et al., 2010; Hosseini et al., 2008; Paraskoei et al., 2017; Kayabasi \& Mtetwa, 2016; Sok et al., 2013; Theodosiou et al., 2012; Mariadoss et al., 2011; and Merrilees et al., 2011).

The analysis results of the second main hypothesis with regard to the direct effect (0.656) showed that the effect of the development of efficiency capabilities on improving the $\mathrm{B} 2 \mathrm{~B}$ performance of the Malayer Furniture Brand was positive. The $\mathrm{t}$-value for the variables 'development of efficiency capabilities' and 'improvement of B2B performance' was 12.201 at a confidence level of $99 \%$ and an error rate of $1 \%$, which was $>2.56$, indicating a significant relationship between these two variables in the Malayer Furniture Brand at a confidence level of $99 \%$. Accordingly, given that the t-value of the second main hypothesis (12.201) is greater than 2.56, the second hypothesis of the study is confirmed.

In other words, the development of efficiency capabilities could justify $656 \%$ of the variations in improving the B2B performance of the Malayer Furniture Brand. Hence the second main research hypothesis was confirmed. In other words, the development of efficiency capabilities has a significant effect on improving the B2B performance of the Malayer Furniture Brand. No evidence rejected the second hypothesis.
This finding is consistent with the findings of some other researchers (e.g., Amiri et al., 2016; Saeidi Garghani \& Naser Asadi, 2016; Mohtaram et al., 2015; Asgari \& Heidari, 2015; Samadi Pour et al., 2015; Rahimi, 2015; Montazeri et al., 2014; Ranjbargi \& Eskandarian, 2014; Monavarian et al., 2014; Elahi et al., 2010; Hosseini et al., 2008; Lockman, 2016; Kayabasi \& Mtetwa, 2016; Merrilees et al., 2011; Tsiotsou \& Vlachopoulou, 2011; Karayanni, 2006; Lin, 2003).

\section{Suggestions According to Hypothesis Testing}

1. According to the results for the first hypothesis:

- The authorities of the studied population are recommended to make efforts to use and apply integrated and coherent processes in order to apply collective skills, knowledge, and resources of the company, identify market needs, and improve the value of their company's goods and services.

- The authorities are also suggested to uniquely rely on other companies or other organizations according to the basic principles of consumer marketing in order to enhance the performance in the product sales or services.

- $\quad$ Regarding the product catalogue index, it is suggested to use an electronic catalogue such as multimedia CDs on a compact disc (CD) with the ability to write a special design, along with the name of the company directly inserted on the $\mathrm{CD}$ to be presented to customers inside a printed or fancy package.

- Regarding the online upgrade index, online communications are suggested to be employed in order to enhance the shopping intention, increase values, or enhance incentives for consumers, wholesalers, retailers, or other company consumers to promote sales promptly. 
Regarding the online order index, the company is recommended to place the list and specifications of its goods on the website so that the buyer, after visiting the website and studying the specifications of the concerned goods can proceed to register the order and purchase the goods from the company.

With regard to the online payment index, the company is recommended to develop and establish a software feature of an online store for the online payments by customers using electronic payment instruments and electronic payment cards (only available on the Internet).

- Regarding the online access index, the salesperson is advised to creating a space on the Internet for its customers to have access to online services whenever they need recommendations or advice to do their online shopping, to ask questions, and to raise their problems.

- Considering the e-shopping index, it is suggested to provide a platform for customers to have e-shopping through online stores so that customers can have shopping.

Regarding the participation in the emarket, it is suggested to provide the necessary grounds through using information and communication technology to expand and deepen partnerships by empowering citizens to further communicate with each other and with their customers.

2. According to the results for the second hypothesis:

The authorities of the studies population are recommended to take steps to improve efficiency capabilities and enhance B2B performance through holding training courses on the principles and foundations of productivity and efficiency. Also, the managers and authorities should consider other factors such as social value of the job, work conditions, and employment products at different times in order to increase the performance.
- Concerning the equality index, it is suggested that the changes in structures and flexibility are considered to improve efficiency and enhance the performance of the employees. Creating trust between managers and the importance of training employees are the factors facilitating efficiency and improving performance. The authorities should pay special attention to this point.

- Regarding the alignment index: (1) All employees should have the same goal. (2) All staff should be aware of how they collaborate in advancing the core strategies to achieve organizational goals. (3) Works, processes, and activities are carried out to achieve the goals. And (4.) Priorities should be simple and transparent.

- Regarding the work speed index, it is recommended to consider the speed of the work and the timely completion of work and daily activities. The faster they can accomplish their tasks during a working day, the more successful they will be. The company should also pay special attention to time management in daily tasks and activities.

Considering the use of facilities, it is recommended to optimally use all the equipment and facilities available in the company to maximize their performance.

\section{References}

Amiri, A. N., Jafari, S. M. B., \& Hosseini Abu Ali, M. (2016). Factors Affecting the Adoption of E-commerce in Iran's Agricultural Sector, Journal of Organizational Culture Management, 14, 541-565.

Asgari, N. \& Heydari, H. (2015). Providing a Model of Factors Affecting Customer Satisfaction and Trust in the E-Commerce Sector (Case Study: Group Discount Websites in Iran), Journal of Information Technology Management, 7(3), 565-674.

Anastasia A. Katou Pawan Budhwar. (2015). Human resource management and organizational productivity, Journal of Organizational Effectiveness: People and Performance, Vol. 2 Issue 3 pp. 244 -266. 
Aydin Kayabasi, Thandiwe Mtetwa, (2016). Impact of marketing effectiveness and capabilities, and export market orientation on export performance: Evidence from Turkey, European Business Review, Vol. 28 Issue: 5 , pp. $532-559$.

Chaffey, D., \& Ellis-Chadwick, F. (2019). Digital marketing. Pearson UK.

Elahi, SH., Hamdan, M., \& Hasanzadeh, A. (2010). On the Relationship between ECommerce and Customer Behavior, ScientificResearch Journal of Behavior Scholor, Shahed University, 16 (35).

Eng, T. Y. and Spickett Jones, J.G. 2009. An investigation of marketing capabilities and upgrading performance of manufacturers in mainland china and Hong Kong. Journal of World Business, 44: 463- 475.

Gary D. Gregory, Liem Viet Ngo, Munib Karavdic. (2017). Developing e-commerce marketing capabilities and efficiencies for enhanced performance in business-to-business export ventures, Industrial Marketing Management,

http://dx.doi.org/10.1016/j.indmarman.2017.03. 002.

Iddris, F. Ibrahim, M. (2015). Examining the relationships between e-marketing adoption and marketing performance of Small and Medium Enterprises in Ghana. Journal of Marketing and Consumer Research, 10(1): 160-169.

Jha, S., Balaji, M. S., Ranjan, K. R., \& Sharma, A. (2019). Effect of service-related resources on employee and customer outcomes in trade shows. Industrial Marketing Management, 76, 48-59.

Karayanni, A. (2006). The effect of culture on creation Marketing intelligence by internet and creation value in organization, Journal of Strategy \& Leadership, VOL. 30 NO. 2.

Kim, H. G., \& Wang, Z. (2019). Defining and measuring social customer-relationship management (CRM) capabilities. Journal of Marketing Analytics, 7(1), 40-50
Hosseini, S. A., Ghazizadeh, M., Abbasi Esfanjani, H. (2008). The effect of Electronic Marketing on the Export Performance of Exporters in the Industrial Sector during 20002005 (with an Emphasis on the Internet), Shahed University, 15(32).

Montazeri, M., Ebrahimi, A., Ahmadi, P., \& Rahnama, A. (2014). Factors Affecting the Intention to Buy in E-Commerce among the Customers of the Computer Websites, Journal of Business Management, 6 (2), 207-226.

Manavarian, A., Manian, A., Movahedi, M., \& Akbari, M. (2014). Factors Affecting the Development of E-Commerce (Case Study: Small and Medium-sized Enterprises in Tehran), Journal of Information Technology Management, 6 (1), 145-160.

Lin, chia Chin (2003) A Critical Appraisal of Customer Satisfaction and E-Commerce's. Managerial Accounting Journal. 8, 3, pp. 202212.

Mariadoss $<$ babu johm; Tanshuja, Patriya silpakit; mouri, Nacef, (2011). Marketing capabilities an innovation-based strategies for environment sustainability: an exploratory investigation of B2B firms, Industrial Marketing Management, 40-1305, 1318

Merrilees, B, Rundle-Thiele, S. Lye, A. (2011). Marketing capabilities: Antecedents and implications for B2B SME performance. Industrial Marketing Management, 40(3), 368375.

Maswera. Tonderai, Dawson. Ray, Janet, Edwards. (2008). E-commerce adoption of travel and tourism organizations in South Africa, Kenya, Zimbabwe and Uganda, Telematics and Informatics 25, pp.187-200.

Mohan, T.T.R. and Ray, S. (2004), "Productivity growth and efficiency in Indian banking: a comparison of public, private and foreign banks", Working Paper No. 2004/27, Department of Economics, University of Connecticut, Connecticut.

Moi, L., Cabiddu, F., \& Frau, M. (2019). Towards the Development of an Agile Marketing Capability. In Organizing for the Digital World (pp. 137-148). Springer, Cham. 
Pierre, A. (2001), "the Evaluation of ECommerce Applications - A Conceptual Framework", Business Administration Department Royal Military College, Canada.

Rahimi, H. (2015). On the Relationship Between Technological Opportunities with an Emphasis on Marketing and Performance of the Company Based on B2B, Third International Conference on Accounting and Management with a New Science Research Approach.

Ranjbargi, A., Eskandarian, GH. (2014). Factors Affecting the Development of E-Commerce Application in Textile and Clothing Companies of Isfahan Province, Journal of Information Technology Management, 6(3), 395-418.

Saeidi Garghani, N., Naserasadi, A. (2016). The Effect of Marketing on the Effectiveness of Ecommerce Strategy Implementation. 6th Conference on New Research in Science and Technology, Tehran.

Samadi Pour, R., Khosh Akhlagh, A., Rezghi Shirsavar, H. (2015). An Evaluation of the Impact of Website Satisfaction and Usability on Productivity Development and Positive Oral Statements in Electronic Banking Services, Journal of Productivity Management, 9 (11), 91110.

Samiee, S. (2008). Global marketing effectiveness via alliances and electronic commerce in business-to-business markets. Industrial Marketing Management, 37(1), 3-8.

Supran Kumar Sharma Raina Dalip. (2014). Efficiency and productivity analysis of Indian banking industry using Hicks-Moorsteen approach, International Journal of Productivity and Performance Management, Vol. 63 Issue 1 pp. $57-84$.

Sadi, A. H. M.; Noordin, M. F. (2011). Factors influencing the adoption of M-commerce: An exploratory Analysis. Proceedings of the 2011 International Conference on Industrial Engineering and Operations Management Kuala Lumpur, Malaysia, January 22-24.

Sok, Phyra; o'Cass, Aron, Momy, Sok, Keo. (2013). achieving superior SME performance: overarching role of marketing, innovation and learning capabilities, Australian marketing journal, 21, 161-167.
Sousa, M. J., Carmo, M., Gonçalves, A. C., Cruz, R., \& Martins, J. M. (2019). Creating knowledge and entrepreneurial capacity for $\mathrm{HE}$ students with digital education methodologies: Differences in the perceptions of students and entrepreneurs. Journal of Business Research, 94, 227-240.

Turban, A., King, D., Lee, J., Warkentin, M., Michael Chung, H., Chung, M. (2006), "Electronic Commerce: A Managerial Perspective", PrenticeHall, second Edition.

Theodosiou M, kehagias J, Katsikea E. (2012). Strategic orientations, Marketing capabilities and firm performance, Journal of Industrial Marketing Management, pp 1-12.

Tsiotsou, R. H. \& Vlachopoulou, M. (2011). Understanding the effects of market orientation and e-marketing on service performance. Marketing Intelligence \& Planning, 29(2): 141155.

Vorhies, D. W., Morgan, R. E., \& Autry, C. W. (2009). Product-market strategy and the marketing capabilities of the Firm: Impact on market effectiveness and cash low performance. Strategic Management Journal, 30(12), 13101334.

Weill, L. (2004), "Measuring Cost Efficiency in European Banking: A Comparison of Frontier Techniques", Journal of Productivity Analysis $21,2$.

Wang, E.T.G., Fen Hu, H., and Hwa Hu, P.J. 2013. Examining the role of information technology in cultivating firms' dynamic marketing capabilities. Information and Management, 50: 336-343.

Wu, J. (2013). Marketing capabilities, institutional development, and the performance of emerging market firms: a multinational study. Intern.J.pf Research in Marketing, 30: 36-45.

Zaman Pour, N., Sattari Ardebili, F. (2015). B2B Marketing for Small and Medium-Sized Enterprises (Case Study: Moghan Corporation), Third International Conference on Management Challenges and Solutions. 
Zhang, Y., Deng, X., Wei, D. \& Deng, Y. (2012). Assessment of E-Commerce security using AHP and evidential reasoning. Expert Systems with Applications, 39(3): 3611-3623.

Zhang, N., Zhou, P., Choi, Y. (2013), "Energy efficiency, $\mathrm{CO} 2$ emission performance and technology gaps in fossil fuel electricity generation in Korea: a metafrontier nonradial directional distance function analysis", Energy Policy 56, 653662. 